\title{
An immunogen synthesis strategy for the development of specific anti-deoxynivalenol monoclonal antibodies
}

Melanie Sanders ${ }^{\mathrm{a}}$, Yirong Guo ${ }^{\mathrm{a}, \mathrm{b}}$, Abhishek Iyer ${ }^{\mathrm{c}}$, Yara Ruiz García ${ }^{\mathrm{c}}$, Anastasia Galvita ${ }^{\mathrm{a}}$, Arne Heyerick $^{\mathrm{d}}$, Dieter Deforce ${ }^{\mathrm{d}}$, Martijn D.P. Risseeuw ${ }^{\mathrm{e}}$, Serge Van Calenbergh ${ }^{\mathrm{e}}$, Marc Bracke ${ }^{\mathrm{f}}$, Sergei Eremin $^{\mathrm{g}}$, Annemieke Madder ${ }^{\mathrm{c}}$ and Sarah De Saeger ${ }^{\mathrm{a}}$

${ }^{\mathrm{a}}$ Laboratory of Food Analysis, Ghent University, Ghent, Belgium; ${ }^{\mathrm{b}}$ Institute of Pesticide and Environmental Toxicology, Zhejiang University, Hangzhou, China; ' Organic and Biomimetic Chemistry Research Group, Ghent University, Ghent, Belgium; ${ }^{\mathrm{d}}$ Laboratory of Pharmaceutical Biotechnology, Ghent University, Ghent, Belgium; ${ }^{\mathrm{e} L a b o r a t o r y ~ f o r ~ M e d i c i n a l ~ C h e m i s t r y, ~ G h e n t ~}$ University, Ghent, Belgium; ' Laboratory of Experimental Cancer Research, Ghent University, Ghent, Belgium; ' ${ }^{\mathrm{D}}$ Department of Chemical Enzymology, Moscow State University, Moscow, Russia

\section{Online Supplementary Material}

The cyclic peptide was synthesized using manual Fmoc solid phase peptide synthesis (SPPS) according to the following procedure:

Coupling of first Amino acid:

Chlorotrityl chloride resin (100 mg, $0.16 \mathrm{mmol}$, loading $=1.6 \mathrm{mmol} / \mathrm{g}$ ) was swollen in dichloromethane (dry, $10 \mathrm{~mL} / \mathrm{g})$ prior to the loading of the first amino acid. Fmoc-Gly-OH $(0.190 \mathrm{~g}$, $0.64 \mathrm{mmol}$ ) was dissolved in dry DCM with N,N'-diisopropylethylamine (DIPEA) (0.22 mL, 1.28 $\mathrm{mmol}$ ) and the reaction was shaken for $3 \mathrm{~h}$. The resin was then washed with $3 \mathrm{x}$ DCM, $3 \mathrm{x}$ DMF, $3 \mathrm{x}$ DCM and was dried under vacuum for $2 \mathrm{~h}$. The loading was determined via Fmoc determination and was calculated to be $0.9 \mathrm{mmol} / \mathrm{g}$ (82\% yield). The resin was then capped with methanol/DIPEA/DCM = 2:1:17 by shaking for $2 \mathrm{~h}$.

Fmoc deprotection for the first amino acid:

The resin was swollen in DMF prior to Fmoc deprotection. A solution of 20\% piperidine in DMF was added to the resin and the mixture was shaken for $30 \mathrm{~min}$. The solution was then washed with $3 \mathrm{x}$ DMF, 3 x methanol, 3 x DMF. This protocol was repeated to ensure complete Fmoc removal.

Coupling for the remaining amino acids:

Fmoc protected glycine (38.9 $\mathrm{mg}, 0.131 \mathrm{mmol})$ along with benzotriazol-1-yl oxytripyrrolidinophosphonium hexafluorophosphate (PyBOP) (273.2 mg, $0.525 \mathrm{mmol}$ ) were dissolved in dry DMF. DIPEA $(0.183 \mathrm{~mL}, 1.048 \mathrm{mmol})$ was added to it and the mixture was shaken for $30 \mathrm{~s}$. The mixture was then added to resin pre-swollen in DMF (dry, $10 \mathrm{~mL} / \mathrm{g}$ ) and the reactor was shaken for $3 \mathrm{~h}$. The solution was filtered followed by washing with $3 \mathrm{x}$ DMF, $3 \mathrm{x}$ methanol, $3 \mathrm{x}$ DMF. Using this protocol, Fmoc-L-Arg(Pbf)-OH, Fmoc-L-Lys(Boc)-OH, Fmoc-D-Phe-OH and Fmoc-LAsp-OH were coupled consecutively.

Fmoc deprotection for the remaining amino acids:

The resin was swollen in DMF prior to Fmoc deprotection. A solution of 20\% piperidine in DMF was added to the resin and the mixture was shaken for $2 \mathrm{~min}, 5 \mathrm{~min}$ and $15 \mathrm{~min}$. The solution was washed with 3 x DMF, 3 x methanol, 3 x DMF after each deprotection step.

Mild acid resin cleavage:

After assembly of the linear peptide, the resin pre-swollen in DCM (dry, $10 \mathrm{~mL} / \mathrm{g}$ ) was treated with trifluoroethanol (TFE)/acetic acid (AcOH)/DCM (1/1/3, v/v/v) for $2 \mathrm{~h}$ to ensure complete cleavage of the protected peptide from the resin. The solvents were evaporated under vacuum and the residual material was analysed using reversed phase (RP)-HPLC/MS (Phenomenex Luna C18 column (250 x $4.6 \mathrm{~mm}, 5 \mu \mathrm{m}$ at $35^{\circ} \mathrm{C}$ ) connected to an ESI mass spectrometer. A mobile phase consisting of $5 \mathrm{mM}$ ammonium acetate (A) and acetonitrile (B) was used at a flow rate of $1 \mathrm{~mL} / \mathrm{min}$. The gradient elution 
programme started with $100 \%$ mobile phase A for 2 min with a linear decrease to $0 \%$ mobile phase A in 15 min. An isocratic gradient of 100\% mobile phase B was continued for 5 min.

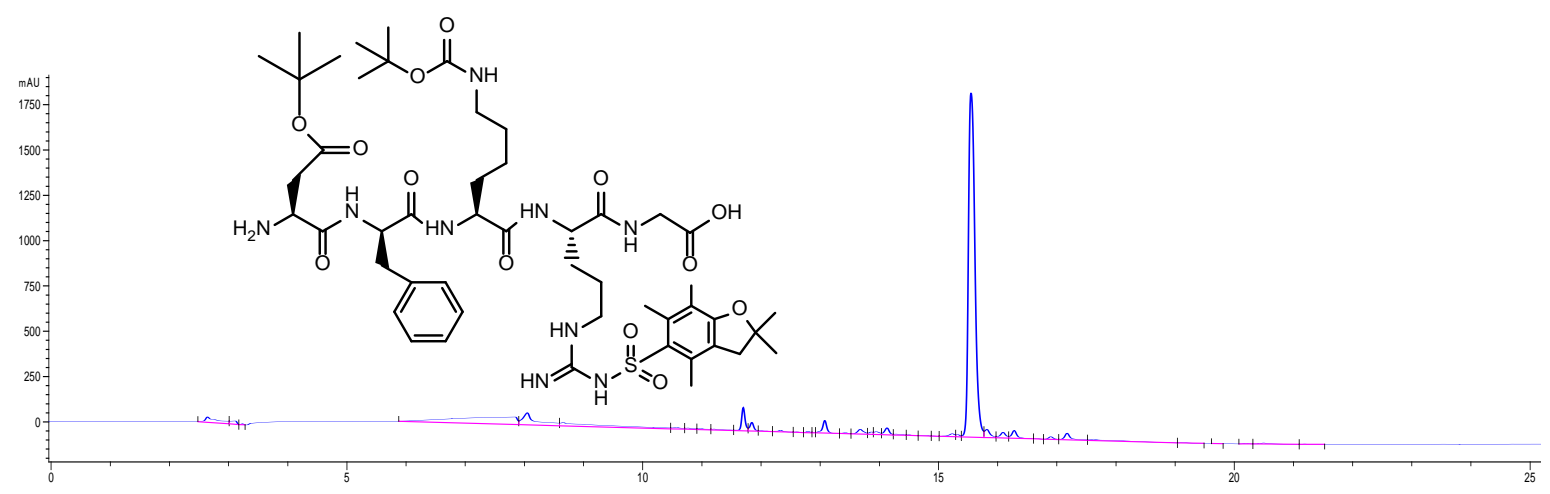

HPLC trace of the protected linear peptide $\left(\mathrm{C}_{49} \mathrm{H}_{75} \mathrm{~N}_{9} \mathrm{O}_{13} \mathrm{~S}\right)$ : eluting at $15.68 \mathrm{~min}$ with calculated $\mathrm{m} / \mathrm{z}$ : 1029.52 and observed $\mathrm{m} / \mathrm{z}\left(\mathrm{ESI}^{+}\right): 1030.4$

Peptide Cyclisation:

The crude linear peptide (77.5 mg, $0.077 \mathrm{mmol}$ ) was dissolved in $5 \mathrm{~mL}$ dry DCM, followed by the addition of 1-hydroxybenzotriazole (HOBt) $(10.4 \mathrm{mg}, 0.077 \mathrm{mmol})$, PyBOP $(40.1 \mathrm{mg}, 0.077 \mathrm{mmol})$ and DIPEA (30.5 mL, $0.175 \mathrm{mmol}$ ). The mixture was stirred for $24 \mathrm{~h}$ at room temperature. Only the cyclic peptide was observed as the main peptide product on HPLC/MS (HPLC/MS conditions same as above).

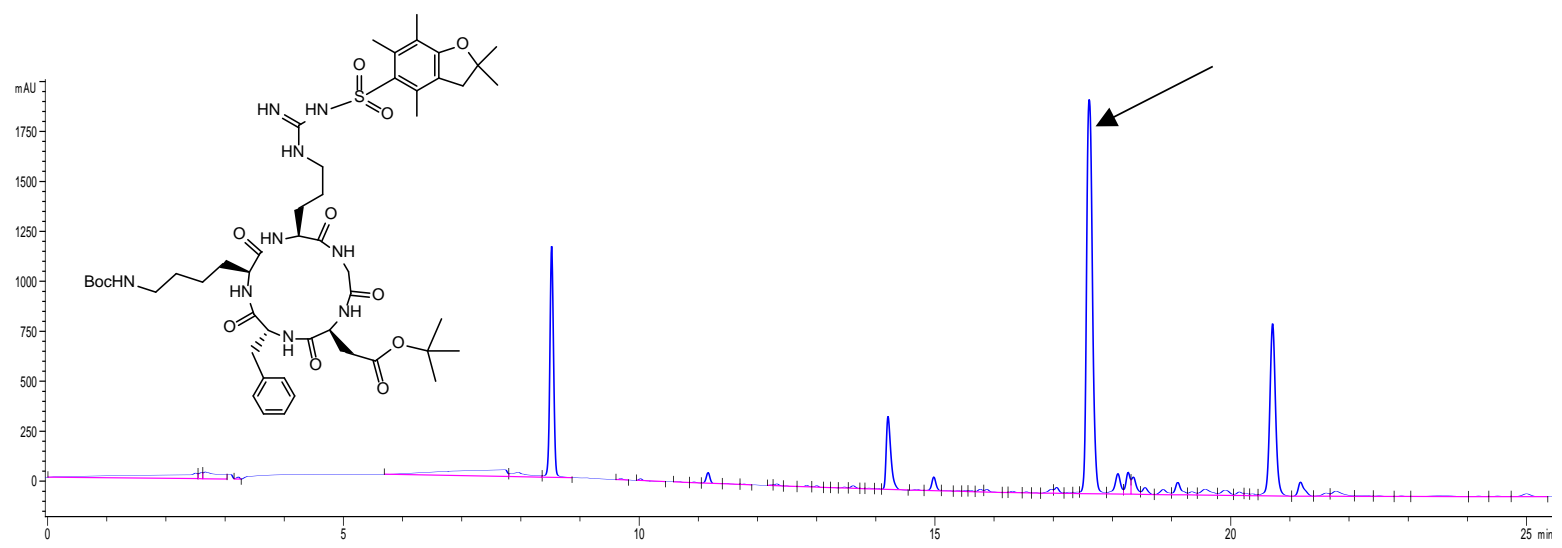

HPLC trace of the protected cyclic peptide $\left(\mathrm{C}_{49} \mathrm{H}_{73} \mathrm{~N}_{9} \mathrm{O}_{12} \mathrm{~S}\right)$ : eluting at $17.66 \mathrm{~min}$ with calculated $\mathrm{m} / \mathrm{z}$ : 1011.53 and observed $\mathrm{m} / \mathrm{z}\left(\mathrm{ESI}^{+}\right)$: 1012.4

Removal of protecting groups:

The reaction mixture was dissolved in $5 \mathrm{~mL}$ TFA/TIS/ $\mathrm{H}_{2} \mathrm{O}(95 / 2.5 / 2.5, \mathrm{v} / \mathrm{v} / \mathrm{v})$ to remove the protecting groups in solution. The peptide was then precipitated in MTBE/Hexane $(1 / 1, \mathrm{v} / \mathrm{v})$ and the reaction mixture was analysed using RP-HPLC/MS (Phenomenex Kinetex C18 $100 \AA$ column $(150 \mathrm{x}$ $4.6 \mathrm{~mm}, 5 \mu \mathrm{m}$ at $35^{\circ} \mathrm{C}$ ) connected to an ESI mass spectrometer. A mobile phase consisting of $5 \mathrm{mM}$ ammonium acetate (A) and acetonitrile (B) was used at a flow rate of $1 \mathrm{~mL} / \mathrm{min}$. The gradient elution programme started with $100 \%$ mobile phase A for 1.5 min with a linear decrease to $0 \%$ mobile phase A in 6 min. An isocratic gradient of 100\% mobile phase B was continued for $2.5 \mathrm{~min}$. 


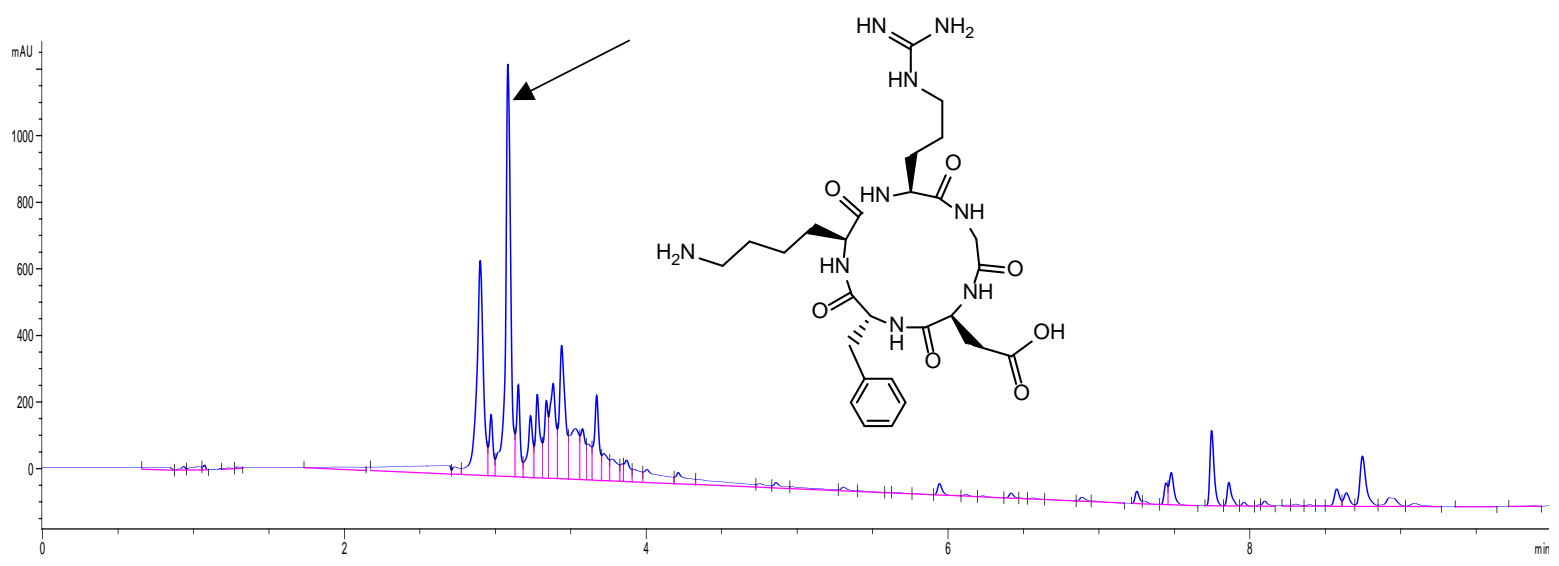

HPLC trace of the deprotected cyclic peptide $\left(\mathrm{C}_{27} \mathrm{H}_{41} \mathrm{~N}_{9} \mathrm{O}_{7}\right)$ ): eluting at $3.10 \mathrm{~min}$ with calculated $\mathrm{m} / \mathrm{z}$ : 603.31 and observed $\mathrm{m} / \mathrm{z}\left(\mathrm{ESI}^{+}\right): 604.2$

Diazo transfer:

A diazo transfer was performed on $50.5 \mathrm{mg}$ of the deprotected cyclic peptide using the imidazole-1sulfonylazide hydrochloride reagent as described by Goddard-Borger and Stick (2007). The conversion was complete and no starting material was observed when analysed with HPLC/MS. The reaction mixture was redissolved in methanol and purified using RP-HPLC.

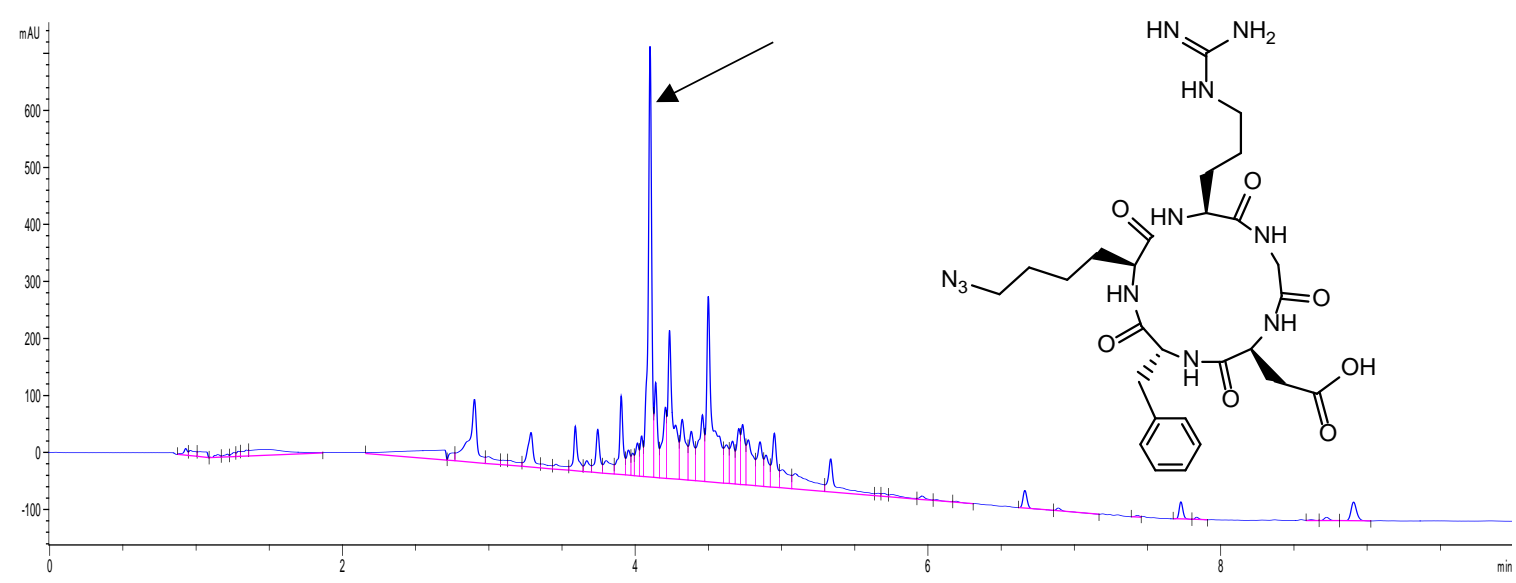

HPLC trace of the deprotected crude cyclic peptide after diazo transfer $\left(\mathrm{C}_{27} \mathrm{H}_{39} \mathrm{~N}_{11} \mathrm{O}_{7}\right)$ : eluting at 4.10 min with calculated $\mathrm{m} / \mathrm{z}: 629.30$ and observed $\mathrm{m} / \mathrm{z}\left(\mathrm{ESI}^{+}\right): 630.2$

HPLC purification of crude peptide:

The crude peptide was purified using RP-HPLC on an Agilent 1100 Series using a Phenomenex semiprep Luna C18 (250 x $10 \mathrm{~mm})$ column. A mobile phase consisting of $0.1 \%$ TFA in $\mathrm{H}_{2} \mathrm{O}(\mathrm{A})$ and acetonitrile (B) was used at a flow rate of $4.5 \mathrm{~mL} / \mathrm{min}$ at $35^{\circ} \mathrm{C}$. The gradient elution programme started with $100 \%$ mobile phase A for 2 min with a linear decrease to $0 \%$ mobile phase A in 15 min. An isocratic gradient of $100 \%$ mobile phase B was continued for 5 min.

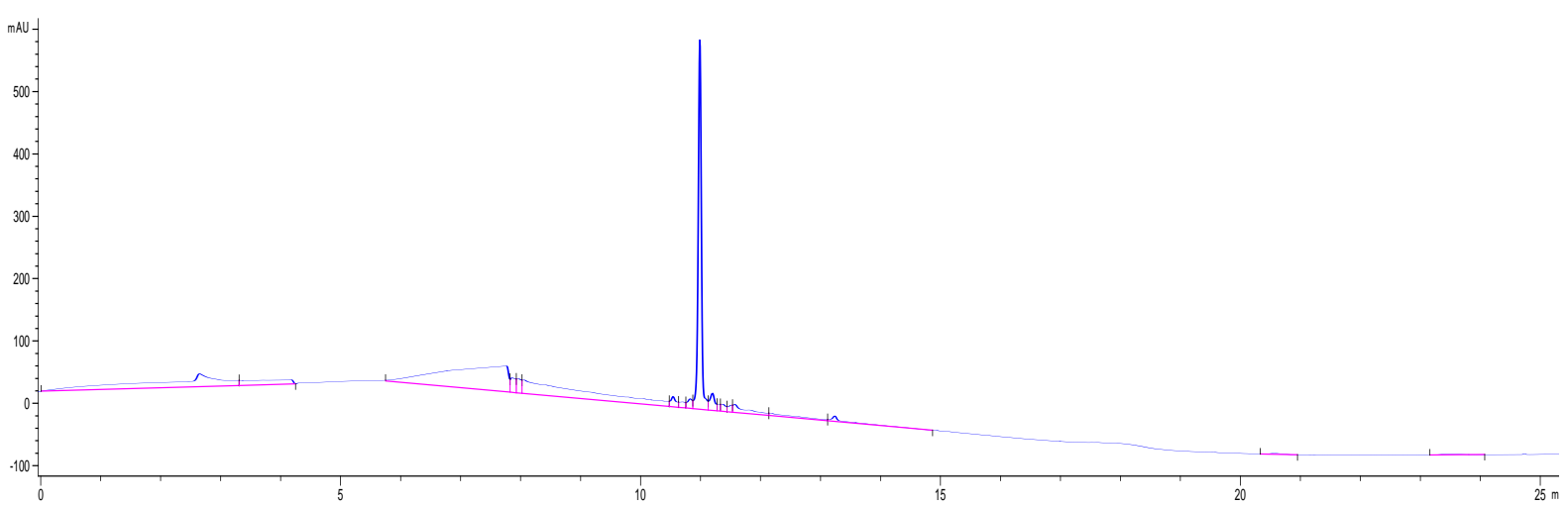


HPLC trace of the final cyclic peptide after HPLC purification eluting at a retention time of $10.95 \mathrm{~min}$.

References:

Dijkgraaf, I., Rijnders, A. Y., Soede, A., Dechesne, A. C., van Esse, G. W., Brouwer, A. J. et al. (2007). Synthesis of DOTA-conjugated multivalent cyclic-RGD peptide dendrimers via 1,3dipolar cycloaddition and their biological evaluation: implications for tumor targeting and tumor imaging purposes. Organic \& Biomolecular Chemistry, 5, 935-944.

Goddard-Borger, E. D. \& Stick, R. V. (2007). An efficient, inexpensive, and shelf-stable diazotransfer reagent: Imidazole-1-sulfonyl azide hydrochloride. Organic Letters, 9, 3797-3800. 